\title{
Blood Chemistry of Normal Human Fetuses at Midtrimester of Pregnancy
}

\author{
FRANCOIS FORESTIER, FERNAND DAFFOS, MARTINE RAINAUT, MARC BRUNEAU, AND \\ FRANCOIS TRIVIN
}

Centre de Diagnostic Prénatal et de Foetologie, Hopital Notre Dame de Bon Secours 75014 [F.F, F.D, M.R]; Laboratoire de biochimie, Hopital Necker 75015 [M.B]; Laboratoire de Biochimie, Hopital Saint Joseph 75014 [F.T], Paris, France

\begin{abstract}
Thirteen biochemical parameters and five enzymatic activities were determined on sera of 63 normal human fetuses sampled by direct puncture under ultrasound guidance, between the 20th and the 26th wk of gestation, and on their mothers. They were referred to us for various prenatal diagnoses but were well and confirmed healthy at birth. Some parameters were found to be very similar in both groups, mainly creatinine, calcium, creatine kinase, aspartate aminotransferase, and $\gamma$-glutamyl transferase. Some values were significantly higher in the fetuses, such as total bilirubin, direct bilirubin, phosphorus, lactic dehydrogenase and alkaline phosphatase activities, and $\alpha$ fetoprotein. Urea, uric acid, glucose, triglycerides, cholesterol, total protein, and albumin levels were found to be lower in fetuses. These data indicate a slower metabolism in fetuses compared to their mothers, a lower level of energy requirement, and a relative liver immaturity. These normal values of fetal biochemistry will improve our knowledge of physiology and help to determine the specific values of a test in fetal pathology. (Pediatr Res 21: 579-583, 1987)
\end{abstract}

Abbreviations
rs, Spearman correlation coefficients
ELISA, enzyme-linked immunosorbent assay

Biochemical studies on neonates (1) report some differences compared with adults. It seems that fetal biochemistry also differs too (2-4) but these studies concerned premature infants with sampling conditions which could affect physiological status. More extensive data obtained for fetuses sampled fetoscopically recently reported ranges for biochemical substances relating to renal, hepatic, and bone function in fetal plasma (5). Pure fetal blood can now be easily obtained by sampling via the umbilical cord, using a needle guided by ultrasound $(6,7)$, allowing the prenatal diagnoses of various diseases $(8-11)$. Regarding congenital toxoplasmosis (10), most of the fetuses (96\%) were found to be well, and gave us the opportunity to obtain normal values in hematology (12), coagulation (13), for free amino acid (14), and in endocrinology $(15,16)$ during the 2 nd trimester of pregnancy. For this study, we retrospectively selected sera from 63 fetuses sampled between the 20th and the 26th wk of gestation, born healthy at term to establish normal fetal biochemical values. Twelve biochemical parameters: total protein, albumin, urea, total bilirubin, direct bilirubin, cholesterol, triglycerides, glucose,

Received June 2, 1986; accepted January 8, 1987.

Correspondence F. Forestier, Centre de diagnostic Prénatal et de Foetologie, Hopital Notre Dame de Bon Secours 75014, Paris, France. creatinine, uric acid, total calcium, phosphorus, and five enzymatic activities: alkaline phosphatase, aspartate aminotransferase, creatine kinase, lactic dehydrogenase and $\gamma$ glutamyl transferase were determined automatically, and $\alpha$-fetoprotein was measured by an immunoassay (ELISA). We also measured maternal blood concentration on the day of the fetal sampling to determine a possible relationship between mothers and their fetuses. The results obtained provide useful normal values, which are a prerequisite for prenatal diagnoses of congenital biochemical disorders, for a better approach to normal and abnormal behavior, and possibly in the future for fetal monitoring.

\section{MATERIALS AND METHODS}

Patients. Sixty-three pure blood samples were selected retrospectively from fetuses that had undergone blood sampling for prenatal diagnosis of congenital toxoplasmosis between the 20th and the 26th wk of gestation, detected to be well in utero, and confirmed healthy at birth. The mothers had a venipuncture on the day of fetal sampling.

Sampling procedure. Fetal blood was obtained by direct puncture of the umbilical vein near the cord insertion on the placenta as previously described $(6,7)$. For this study, $2 \mathrm{ml}$ were obtained and divided into three aliquots: one anticoagulated with EDTA to control purity, one anticoagulated with fluorure oxalate to determine glucose level, and another without additive. Histograms of white and red blood cells provided by a Coulter $S$ plus II were automatically recorded and compared with those for maternal blood samples. The Kleihauer Betke staining procedure and isoelectric focusing of hemoglobin were carried out to detect maternal blood contamination. Pure fetal blood was obtained in all cases, without dilution by amniotic fluid or contamination by maternal blood. Blood samples were left $2 \mathrm{~h}$ at room temperature for clotting, then the sera (as plasma) were separated by centrifugation and frozen at $-80^{\circ} \mathrm{C}$ until the time of assays.

Biochemical measurements. A multipurpose chemistry analyser, Coulter dacos (discrete analyzer with continuous optical scanning) was used to determine 12 blood substrate concentrations and five enzymatic activities with dart reagents (Coulter Electronics Inc, Hialeah, FL). The required specimen volume ranges between 2 and $20 \mu \mathrm{l}$ for each test, so only $150 \mu \mathrm{l}$ were required for those 17 determinations.

The principles and procedures of these biochemical analyses have been previously described in detail, and are summarized below. Albumin was determined by a modification of the method of Doumas (bromocresol green) (17), the instantaneous initial absorbance at $630 \mathrm{~nm}$ was obtained as suggested by Webster (18). Urea nitrogen was determined by a modification of the method of Marsh et al. (19) (urease). The method used to determine total bilirubin and direct bilirubin was a modification of the Walters and Gerarde (20) method (diazoreaction with 
sulfanilic acid). The kinetic formation of the diazo dye is different depending on which of the following three derivatives is involved (monoglucuronide, diglucuronide, or unconjugated bilirubin). Bilirubin diglucuronides and a part of the monoglucuronides give the direct reaction. Total bilirubin includes the three bilirubin derivatives. In the presence of cholesterol oxidase and oxygen, the cholesterol is oxidized to cholesten-3-one and hydrogen peroxide. Hydrogen peroxide with a peroxidase, couples a 4aminoantipyrine and phenol in a quinonimine with an absorbtion at $500 \mathrm{~nm}$. Triglycerides were determined by a modification of the method of Bucolo and David (21) (triglycerol lipase, glycerol kinase). Uric acid was determined by a modification of the method of Fossati et al. (22) (uricase). To determine glycemia, we used a modified hexokinase/glucose-6-phosphate dehydrogenase procedure, which is a national glucose reference method (23). Total protein was measured by a Gornall method, where the color reaction is the basis for biuret test (24). The method used for creatinine is a modification of the kinetic Jaffe method (25). Calcium was determined by a modification of the method of Connerty and Briggs (26) (O-cresolphthalein complexone). Phosphorus was determined by a modification of the method of Daly and Ertingshausen (27) (phosphomolybdate coloration). The method used to determine alkaline phosphatase activity was optimized from Bowers and McComb (28) system ( $p$-nitrophenylphosphate). Aspartate aminotransferase activity was determined by a modification of the method optimized by Bergmeyer et al. (29). Creatine kinase activity was measured according to the method of Rosalki (30). The reagent includes AMP and diadenosine pentaphosphate to suppress adenylate kinase activity (31). Lactate dehydrogenase activity was determined by a modification of the method of Wacker et al. (32). Gamma-glutamyl transpeptidase activity was determined by a modification of Szasz's method (33). Reagents were prepared as directed by the manufacturers. Dart calibrators (Coulter Electronics) and internal quality control were used. Alpha-fetoprotein is determined through an immunoassay (ELISA) (TANDEM AFP Biotrol).

Statistical studies. For the 17 biochemical parameters studied on 63 pairs of maternal-fetal blood, reference values were established with means, $\mathrm{SD}$, and confidence limits related to mean. Histograms were constructed. The distribution curve was found to be non-Gaussian. In order to establish the biochemical profile of fetuses, results between 2.5 and 97.5 percentiles were taken into account. rs were computed from the two series of data (collected in fetuses and in pregnant women) in order to shed light on the differences or similarities between these measures. The decision making procedure used in testing the significance of a measure was determined by computing the test (34).

\section{RESULTS}

The results obtained for 63 normal human fetuses and their mothers (means $\pm \mathrm{SD}$ ) between the 20th and 26th wk of gestation are given in Table 1 for sera substrate concentrations and in Table 2 for sera enzymatic activities.

The concentrations of two substrates studied are not significantly different in either group: creatinine [64 $\pm 2 \mu \mathrm{mol} /$ liter $(0.726 \pm 0.021 \mathrm{mg} / \mathrm{dl})$ in fetal sera; $67 \pm 1.5 \mu \mathrm{mol} /$ liter $(0.765$ $\pm 0.016 \mathrm{mg} / \mathrm{dl})$ in maternal sera] and calcium $[2.25 \pm 0.2 \mathrm{mmol} /$ liter $(9.02 \pm 0.8 \mathrm{mg} / \mathrm{dl}) / 2.27 \pm 0.1 \mathrm{mmol} / \operatorname{liter}(9.10 \pm 0.40 \mathrm{mg} /$ dl)]. The concentrations of the other substrates were found to be significantly different in human fetal sera compared with those in their mothers. Phosphorus: $2.65 \pm 0.1 \mathrm{mmol} / \mathrm{liter}(8.31 \pm$ $0.29 \mathrm{mg} / \mathrm{dl})$, total bilirubin: $26.8 \pm 1 \mu \mathrm{mol} / \mathrm{liter}(1.57 \pm 0.06$ $\mathrm{mg} / \mathrm{dl})$ and direct bilirubin $16.1 \pm 0.6 \mu \mathrm{mol} / \mathrm{l}(0.943 \pm 0.035$ $\mathrm{mg} / \mathrm{dl}$ ) are significantly higher in fetuses, as against maternal concentrations [phosphorus: $1.45 \pm 0.1 \mathrm{mmol} / 1(4.55 \pm 0.18$ $\mathrm{mg} / \mathrm{dl})$, total bilirubin: $8.6 \pm 0.4 \mu \mathrm{mol} / \mathrm{l}(0.504 \pm 0.025 \mathrm{mg} / \mathrm{dl})$ and direct bilirubin: $0.9 \pm 0.4 \mu \mathrm{mol} / \mathrm{liter}(0.05 \pm 0.02 \mathrm{mg} / \mathrm{dl})]$. Total serum fetal protein represents half that of maternal serum concentration. Fetal albumin is also lower, as are glucose $2.8 \pm$
Table 1. Comparative fetal (20-26th wk) and maternal biochemistry (mean and SD)

\begin{tabular}{lcc} 
& \multicolumn{3}{c}{ Fetuses } & $\begin{array}{c}\text { Mothers } \\
(n=63)\end{array}$ & $(n=63)$ \\
\hline Glucose & $2.8 \pm 0.2 \mathrm{mmol} / \mathrm{liter}$ & $4.4 \pm 0.1 \mathrm{mmol} / \mathrm{liter}$ \\
& $(51 \pm 3.8 \mathrm{mg} / \mathrm{dl})$ & $(79 \pm 1.8 \mathrm{mg} / \mathrm{dl})$ \\
Triglycerides & $0.89 \pm 0.03 \mathrm{mmol} / \mathrm{liter}$ & $1.4 \pm 0.07 \mathrm{mmol} / \mathrm{liter}$ \\
& $(78 \pm 2 \mathrm{mg} / \mathrm{dl})$ & $(122 \pm 6 \mathrm{mg} / \mathrm{dl})$ \\
Cholesterol & $1.5 \pm 0.05 \mathrm{mmol} / \mathrm{liter}$ & $6.6 \pm 0.2 \mathrm{mmol} / \mathrm{liter}$ \\
& $(58 \pm 2 \mathrm{mg} / \mathrm{dl})$ & $(255 \pm 7 \mathrm{mg} / \mathrm{dl})$ \\
Total protein & $30.4 \pm 0.6 \mathrm{~g} / \mathrm{liter}$ & $69.6 \pm 0.9 \mathrm{~g} / \mathrm{liter}$ \\
& $(3.04 \pm 0.06 \mathrm{~g} / \mathrm{dl})$ & $(6.96 \pm 0.09 \mathrm{~g} / \mathrm{dl})$ \\
Albumin & $21.4 \pm 0.4 \mathrm{~g} / \mathrm{liter}$ & $34.9 \pm 0.5 \mathrm{~g} / \mathrm{liter}$ \\
& $(2.14 \pm 0.04 \mathrm{~g} / \mathrm{dl})$ & $(3.49 \pm 0.05 \mathrm{~g} / \mathrm{dl})$ \\
Calcium & $2.25 \pm 0.2 \mathrm{mmol} / \mathrm{liter}$ & $2.27 \pm 0.1 \mathrm{mmol} / \mathrm{liter}$ \\
& $(9.02 \pm 0.8 \mathrm{mg} / \mathrm{dl})$ & $(9.1 \pm 0.4 \mathrm{mg} / \mathrm{dl})$ \\
Phosphorus & $2.65 \pm 0.1 \mathrm{mmol} / \mathrm{liter}$ & $1.45 \pm 0.1 \mathrm{mmol} / \mathrm{liter}$ \\
& $(8.31 \pm 0.29 \mathrm{mg} / \mathrm{dl})$ & $(4.55 \pm 0.18 \mathrm{mg} / \mathrm{dl})$ \\
Urea & $2.6 \pm 0.16 \mathrm{mmol} / \mathrm{liter}$ & $4.3 \pm 0.2 \mathrm{mmol} / \mathrm{liter}$ \\
& $(16 \pm 0.1 \mathrm{mg} / \mathrm{dl})$ & $(26 \pm 0.1 \mathrm{mg} / \mathrm{dl})$ \\
Creatinine & $64 \pm 2 \mu \mathrm{mol} / \mathrm{liter}$ & $67 \pm 1.5 \mu \mathrm{mol} / \mathrm{liter}$ \\
& $(0.726 \pm 0.021 \mathrm{mg} / \mathrm{dl})$ & $(0.765 \pm 0.016 \mathrm{mg} / \mathrm{liter})$ \\
Uric acid & $167 \pm 10 \mu \mathrm{mol} / \mathrm{liter}$ & $215 \pm 9.5 \mu \mathrm{mol} / \mathrm{liter}$ \\
& $(2.80 \pm 0.17 \mathrm{mg} / \mathrm{dl})$ & $(3.62 \pm 0.16 \mathrm{mg} / \mathrm{dl})$ \\
Total bilirubin & $26.8 \pm 1 \mu \mathrm{mol} / \mathrm{liter}$ & $8.6 \pm 0.4 \mu \mathrm{mol} / \mathrm{liter}$ \\
& $(1.57 \pm 0.06 \mathrm{mg} / \mathrm{dl})$ & $(0.504 \pm 0.025 \mathrm{mg} / \mathrm{dl})$ \\
Direct bilirubin & $16.1 \pm 0.6 \mu \mathrm{mol} / \mathrm{liter}$ & $0.9 \pm 0.4 \mu \mathrm{mol} / \mathrm{liter}$ \\
& $(0.943 \pm 0.035 \mathrm{mg} / \mathrm{dl})$ & $(0.05 \pm 0.02 \mathrm{mg} / \mathrm{dl})$ \\
\hline & &
\end{tabular}

Table 2. Comparative fetal and maternal enzymatic activities (IU/liter) (mean and SD)

\begin{tabular}{lcc}
\hline & $\begin{array}{c}\text { Fetuses } \\
(n=63)\end{array}$ & $\begin{array}{c}\text { Mothers } \\
(n=63)\end{array}$ \\
\hline Creatine kinase & $62 \pm 6$ & $48 \pm 2$ \\
Lactic dehydrogenase & $261 \pm 14$ & $132 \pm 5$ \\
Aspartate aminotransferase & $21.1 \pm 2$ & $12.9 \pm 1$ \\
Alkaline phosphatase & $197 \pm 11$ & $60 \pm 3$ \\
$\gamma$-glutamyl transferase & $24.4 \pm 9.6$ & $19 \pm 10$ \\
\hline
\end{tabular}

$0.2 \mathrm{mmol} / \mathrm{liter}(51 \pm 3.8 \mathrm{mg} / \mathrm{dl}) / 4.4 \pm 0.1 \mathrm{mmol} / \mathrm{liter}(79 \pm 1.8$ $\mathrm{mg} / \mathrm{dl})$, urea $2.6 \pm 0.16 \mathrm{mmol} /$ liter $(16 \pm 0.1 \mathrm{mg} / \mathrm{dl}) / 4.3 \pm 0.2$ $\mathrm{mmol} /$ liter $(26 \pm 0.1 \mathrm{mg} / \mathrm{dl})$ and uric acid $167 \pm 10 \mu \mathrm{mol} / \mathrm{liter}$ $(2.80 \pm 0.17 \mathrm{mg} / \mathrm{dl}) / 215 \pm 9.5 \mu \mathrm{mol} /$ liter $(3.62 \pm 0.16 \mathrm{mg} / \mathrm{dl})$. Fetal triglycerides and cholesterol concentrations are also very low $[0.89 \pm 0.03 \mathrm{mmol} / \mathrm{l}(78 \pm 2 \mathrm{mg} / \mathrm{dl})$ for triglycerides and $1.5 \pm 0.05 \mathrm{mmol} /$ liter $(58 \pm 2 \mathrm{mg} / \mathrm{dl})$ for cholesterol $]$ as opposed to maternal values [triglycerides: $1.4 \pm 0.07 \mathrm{mmol} /$ liter $(122 \pm$ $6 \mathrm{mg} / \mathrm{dl})$ and cholesterol: $6.6 \pm 0.2 \mathrm{mmol} /$ liter $(255 \pm 7 \mathrm{mg} /$ $\mathrm{dl})]$.

Aspartate aminotransferase, creatine kinase, and $\gamma$-glutamyl transferase activities are not different in either group. Alkaline phosphatase and lactic dehydrogenase activities in fetal sera (alkaline phosphatase: $197 \pm 11$ IU/liter, lactic dehydrogenase: $261 \pm 14 \mathrm{IU} /$ liter) are greater than in maternal sera (alkaline phosphatase: $60 \pm 3 \mathrm{IU} /$ liter, lactic dehydrogenase: $132 \pm 5 \mathrm{IU} /$ liter). The results obtained for $\alpha$-fetoprotein measurement in 89 fetal blood samples and their related maternal sera and amniotic fluid are summarized in Figure 1. Except for triglycerides, the levels of which progressively decreased during the $6 \mathrm{wk}$ studied, and for $\alpha$-fetoprotein, no correlations were observed between gestational age and blood concentrations for the other biochemical parameters or enzymatic activities. Triglycerides values are proportional to gestational age with the following formula: $\mathrm{y}=$ 

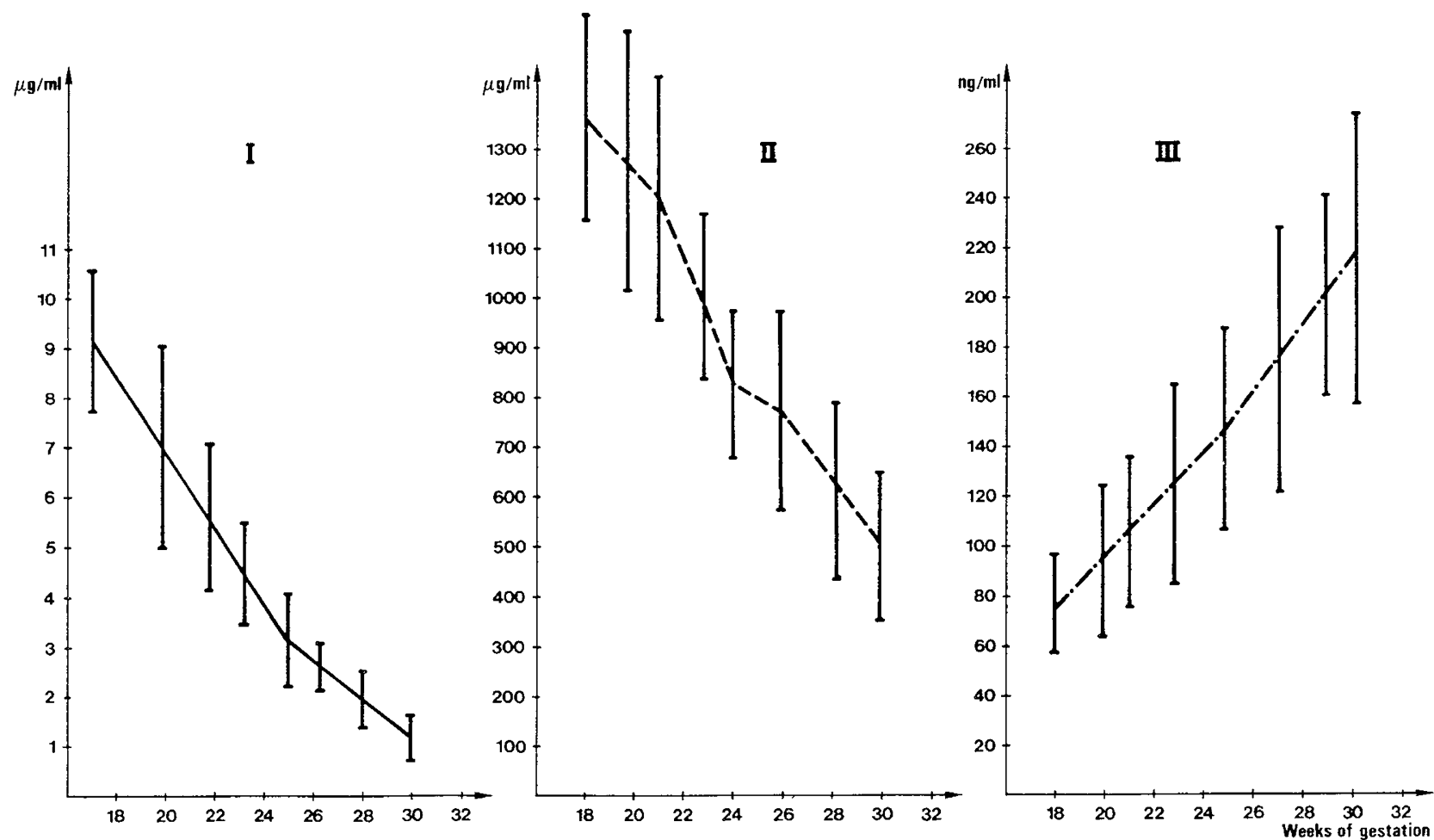

Fig. 1. Alpha-fetoprotein levels in 89 mothers and their related fetuses (mean $\pm \mathrm{SD}$ ), in amniotic fluid $(I)$, in fetal sera $(I I)$, and in maternal sera (III).

$26.5-15.9 \mathrm{x}(\mathrm{y}=$ triglycerides levels, $\mathrm{x}=$ gestational age, with $r$ $=0.614$ ).

rs are calculated for 11 parameters to assess a possible link between maternal and fetal concentrations. Correlation is obtained for urea ( $\mathrm{rs}=0.765)$, glucose $(\mathrm{rs}=0.631)$, creatinine ( $\mathrm{rs}$ $=0.849$ ), and uric acid ( $\mathrm{rs}=0.765$ ); and no correlation is found for cholesterol $(\mathrm{rs}=-0.137)$, triglycerides ( $\mathrm{rs}=-0.190)$, total protein ( $\mathrm{rs}=-0.112$ ), and for enzymatic activities: creatine kinase ( $\mathrm{rs}=0.124)$, lactic dehydrogenase $(\mathrm{rs}=0.119)$, aspartate aminotransferase ( $\mathrm{rs}=0.042$ ), and alkaline phosphatase ( $\mathrm{rs}=$ $0.041)$.

\section{DISCUSSION}

Normal values of biochemical parameters are clearly established for neonates as well as for premature infants (1). Past studies on the biochemical constituents of fetal blood were taken from fetuses which had been aborted and were therefore restricted to a few selective parameters (2-4). More recently, Moniz et al. (5) reported normal reference ranges for biochemical substances relating to renal, hepatic and bone functions, in fetal blood obtained by fetoscopy in the second trimester of pregnancy, and in maternal plasma (5). In the present study, the normal values of 13 blood substrate concentrations and five enzymatic activities were determined in samples obtained by direct puncture under ultrasound guidance from normal human fetuses between the 20th and 26th wk of gestation. Compared with earlier studies on term neonates, the main differences concern the levels of albumin and total protein which are lower during early fetal life. The amount of $\alpha$-fetoprotein progressively decreases from the 18th to 30th wk of gestation ranging from $1344 \pm 353$ to $512 \pm 195 \mu \mathrm{g} / \mathrm{ml}$. These data correlate well with the previously reported decrease of $\alpha$-fetoprotein in amniotic fluid during this period (19). In the present study the data ranged from $9.1 \pm 2.1 \mu \mathrm{g} / \mathrm{ml}$ at the 18 th wk to $1.36 \pm 0.56 \mu \mathrm{g} / \mathrm{ml}$ at the 30 th wk. This supports the hypothesis of the decreased synthesis of $\alpha$-fetoprotein during gestation (36). In maternal sera we observed a decrease of $\alpha$-fetoprotein levels. If we take into consid- eration the albumin $/ \alpha$-fetoprotein ratio during the gestational period studied, there is a significant decrease which could be connected with fetal liver maturity. Some recent studies suggest that $\alpha$-fetoprotein could bind bilirubin as does albumin (37). That relationship between albumin and $\alpha$-fetoprotein needs to be investigated more deeply in order to assess fetal development and maturity (38) as well as the measurement of growth-promoting activity (16). Comparing these figures with those registered for adults, we found the same discrepancy for albumin and total protein, due to the fact that at birth, the levels are the same as in the adult. The very low fetal plasma protein concentration bears out the hypothesis that the placenta is sparingly permeable to proteins.

Fetal glucose values are half that in the adult, but in good correlation with the maternal level $(\mathrm{rs}=0.631)$. Fetal triglycerides are also lower and progressively decrease with a minimum level at birth $(39,40)$. As for albumin and total amino acid levels (14), the decrease of glucose and triglycerides levels in fetuses will involve a reduction of energy supply.

As with other structural substrates, fetal cholesterol was found to be very low (one-fifth of the maternal level). This could reflect a fast utilization in lipid building and a very high lipid turnover during fetal life. Another hypothesis concerns the liver immaturity of fetuses at this stage of development which is demonstrated by the measurement of low activities of coagulation factors synthesized by the liver (13).

Total serum calcium concentration was found at the same level in fetuses and mothers, despite low protein and high phosphorus concentrations in the fetuses. There was no correlation between the maternal and fetal calcium, total protein, and phosphorus concentrations. These results are in good correlation with Thalme's (3) reports on aborted products, and we can hypothesize that even if total calcium concentrations are the same in mothers and fetuses, there are some differences in repartition between free and protein-bound calcium. Citrate concentration and the calcium-binding capacity of proteins in fetuses $(3,4)$ cannot explain the absence of correlation between calcium and 
total protein in fetuses. So with the same fetal calcium concentration, if fetal total protein is less than half of maternal total protein concentration, the fetal ionized calcium concentration must be higher than in mothers, as is the case with the serum phosphorus concentration. Calcium phosphates are poorly dissociated at neutral $\mathrm{pH}$ and it seems that placenta is less permeable to undissociated calcium phosphate than to calcium and phosphate ions. Radde et al. (41) prove the existence of a fetomaternal gradient for ionized calcium where placenta plays an active role. This specialized transport has been suggested to be facilitated by the placental calcium pump (42). There is also an active transfer of phosphorus. Calcium and phosphorus metabolism and transplacental movements concur in obtaining high levels of calcium and phosphorus ions in fetal sera. This, associated with high fetal alkaline phosphatase activities (which is probably of bone origin) (5), could reflect a specific aspect of bone building.

Fetal creatinine level is not different from the level registered in mothers. In contrast the level of urea (the most diffusible molecule) is lower in fetuses. This contradicts animal studies which reported that fetal plasma urea concentrations were higher than maternal values; and there was a constant fetal-maternal gradient across the placenta, over a wide range of urea concentration (43). Two mechanisms can explain the low level of urea in fetal sera: a poor reabsorption of water by the convoluted tubules of the kidney which increases the clearance of urea in fetuses and a liver immaturity that involves a decrease of amino acid metabolism with a lower generation of urea. In fact the convoluted tubules of the kidney seem to be functional because ions were correctly reabsorbed, therefore the low levels of fetal uremia must be related to a poor production of urea. In addition, amino acid level is lower in fetuses than in adults (14). Uric acid, as a reflection of cellular replacement, is also lower in fetuses. The study of uric acid precursors in fetuses may tell us if this low level is related to a decreased production or to an increase in the metabolism and elimination.

The total amount of bilirubin is significantly higher and does not differ from that observed at birth (1). As suggested by Moniz et al. (5), the causes of hyperbilirubinaemia must be considered. First, the fetal erythrocytes have a shortened life span of about 70 days (44), and second, the conjugating ability of the liver is still immature. Because of the relatively high level of direct bilirubin, it is necessary to investigate bilirubin mono- and diconjugates. Indeed the presence of bilirubin conjugates in fetal blood could reflect an immaturity of internal liver bile ducts, which could be explored through a study of biliary acids. This observation is usually typical of a retentional syndrome of the bile ducts. However, this goes against the observation that $20 \%$ of neonates are born with a failure of glucuronidation. As a matter of fact the fetal liver would only metabolize a minimal part of the bilirubin, with a lack of elimination most of it is eliminated by maternal liver metabolism. The observation of five pregnancies with severe rhesus isoimmunization, which gave us the opportunity to manage fetal blood transfusion in utero, has allowed the study of fetal bilirubin elimination. We never observed any increase of fetal bilirubin, due to the fact that bilirubin is eliminated by the maternal liver.

rs were calculated from the data from 63 fetuses and their related mothers in order to point out a possible correlation between maternal and fetal levels of biochemical substrates and enzymes. For urea, creatinine, glucose, and uric acid, the rs values are higher than 0.6 . These data indicate that there is a correlation between maternal and fetal concentrations. From a clinical point of view the measurements of those fetal parameters are not relevant for diagnostic use in utero. For example, an increase of fetal creatinine does not reflect renal insufficiency. In fact we handled a case of severe hydronephritis without alteration of fetal creatinine levels. Spearman coefficient were found to be less than 0.2 for cholesterol, triglycerides, total protein, creatine kinase, lactic dehydrogenase, aspartate aminotransferase, and alkaline phosphatase suggesting that a specific value of those parameters is a real reflection of fetal status. The data provided by these statistical analyses and our reference values greatly contributed to two types of diagnosis. First, after demonstrating that cholesterol in a fetus of $24 \mathrm{wk}$ was one-fifth that of its mother and that there is no correlation between maternal and fetal levels, we have been able to perform the first prenatal diagnosis of hypercholesterolemia in an affected homozygous fetus. The level found was $14.04 \mathrm{mmol} / \mathrm{liter}(543 \mathrm{mg} / \mathrm{dl})$, contrasting with our usual values $1.5 \pm 0.05 \mathrm{mmol} / \mathrm{liter}(58 \pm 2 \mathrm{mg} /$ dl). These data were confirmed by the absence of binding of low density lipoprotein receptor activity on fibroblasts (Goldstein JL, Brown MS, unpublished data) and were confirmed on the aborted fetus (11). Second, in cases of congenital toxoplasmosis we usually observed an increase of $\gamma$-glutamyl transferase and lactic dehydrogenase. Gamma-glutamyl transferase in 163 normal fetuses at risk of toxoplasmosis was $30 \pm 10$ and $180 \pm 80$ IU/liter in affected fetuses (10). Lactic dehydrogenase was, respectively, $279 \pm 50$ and $480 \pm 110 \mathrm{IU} /$ liter. The increase of $\gamma$ glutamyl transferase and lactic dehydrogenase might suggest liver damage. In future these measurements will be helpful as early nonspecific diagnostic markers.

In conclusion, the study reported normal ranges of biochemical parameters in pure fetal blood from healthy fetuses. They have been obtained by the use of a new technique for fetal blood sampling in utero. This knowledge has become indispensable for prenatal diagnoses of biochemical disorders and for further examination of affected fetuses. The correlation observed between the different biochemical levels either in cord sera or in maternal sera or between both pave the way for future studies concerning fetal metabolism. Other reference ranges of biochemical indices need to be established, thus widening the scope for the prenatal diagnosis of other conditions.

Acknowledgments. The authors thank A. Gregoire for the measurements of $\alpha$-fetoprotein, J. Pigeard for technical assistance, W. Cox for language revisions, and A. M. Soumagnac for typing the manuscript.

\section{REFERENCES}

1. Charritat JL, Polonovski C 1984 Normes biologiques pédiatriques. Encycl Med Chir (Paris, France), Pédiatrie 4002 F 30, 4.10.01

2. Hyvarinen M, Zelter P, Oh W, Stiehm ER 1973 Influence of gestational age on serum levels of alpha-fetoprotein, IgG globulin and albumin in newborn infants. J Pediatr 82:430-437

3. Thalme B 1971 Potassium, sodium, chloride, total protein calcium and inorganic phosphorus in plasma of human fetuses and newborn infants. Biol Neonate 18:444-456

4. Sann L 1974 Le métabolisme phosphocalcique du foetus. Pediatrie 29:760 768

5. Moniz CF, Nicolaides $\mathrm{KH}$, Bamforth FJ, Rodeck CH 1985 Normal reference ranges for biochemical substances relating to renal, hepatic and bone function in fetal and maternal plasma throughout pregnancy. $\mathrm{J}$ Clin Pathol 38:468472

6. Daffos F, Capella-Pavlovsky M, Forestier F 1983 Fetal blood sampling via the umbilical cord using a needle guided by ultrasound. Report of 66 cases. Prenat Diagn 3:271-277

7. Daffos F, Capella-Pavlovsky M, Forestier F 1985 Fetal blood sampling during pregnancy with use of a needle guided by ultrasound. A study of 606 consecutive cases. Am J Obstet Gynecol 153:655-660

8. Forestier F, Daffos F, Solé Y, Rainaut M 1986 Prenatal diagnosis of haemophilia by fetal blood sampling under ultrasound guidance. Haemotasis 16:346-351

9. Daffos F, Forestier F, Kéros-Grangeot L, Capella-Pavlovsky M, Lebon P Chartier M, Pillot J 1984 Prenatal diagnosis of congenital rubella. Lancet $2: 1-3$

10. Desmonts G, Daffos F, Forestier F, Capella-Pavlovsky M, Thulliez P, Chartier M 1985 Prenatal diagnosis of congenital toxoplasmosis. Lancet 1:500-504

11. De Gennes JL, Daffos F, Dairou F, Forestier F Capella-Pavlovsky M, Truffert J, Gaschard JC, Darbois Y 1985 Direct fetal blood examination for prenatal diagnosis of homozygous familia hypercholesterolemia. Arteriosclerosis $5 ; 440-442$

12. Forestier F, Daffos F, Galactéros F, Bardakjian J, Rainaut M, Beuzard Y 1986 Hematological values of 163 normal fetuses between 18 and 30 weeks of gestation. Pediatr Res 20:342-347

13. Forestier F, Daffos F, Rainaut M, Solé Y, Amiral J 1985 Vitamin K dependen 
proteins in fetal hemostasis at mid trimester of pregnancy. Thromb Haemostas 53:401-403

14. Kamoun P, Droin V, Forestier F Daffos F, 1985 Free amino acids in human fetal plasma. Clin Chim Acta 150:227-230

15. Nahoul K, Daffos F, Forestier F, Scholler R 1985 Cortisol, cortisone and dehydroepiandrosterone sulfate levels in umbilical cord and maternal plasma between 21 and 30 weeks of pregnancy. J Steroid Biochem 23:445-450

16. Thierot-Prévost G, Daffos F, Forestier F, Job JC 1986 Serum somatomedin C, bioassayable growth promoting activity (thymidine activity) and transferrin in human fetuses: in utero study. Pediatr Res 20:71-73

17. Doumas BT, Watson WA, Biggs HG 1971 Albumin standards and the measurement of serum albumin with bromocresol green. Clin Chem Acta 31:8796

18. Webster D 1977 The immediate reaction between bromocresol green and serum as a measure of albumin content. Clin Chem 23:663-665

19. Marsh WH, Fingerhut B, Miller H 1965 Automated and manual direct methods for the determination of blood urea. Clin Chem 11:624-627

20. Walters M, Gerarde H 1970 An ultra-micromethod for the determination of conjugated and total bilirubin in serum or plasma. Microchem $\mathbf{J}$ 15:231243

21. Bucolo G, David H, 1973 Quantitative determination of serum triglycerides by the use of enzymes. Clin Chem 19:476-482

22. Fossati P, Prencipe L, Berti G 1980 Use of 3,5-Dichloro-2-hydroxybenzenesulfonic acid/4-aminophenazone chromogenic system in direct enzymatic assay of uric acid in serum and urine. Clin Chem 26:227-231

23. 1976 National Glucose Reference Method. Publication (CDC) 77.8830, U.S Department of Health, Education and Welfare, Washington, DC

24. Gornall AG, Bardawill CJ, David MM 1949 Determination of serum proteins by means of the biuret reaction. J Biol Chem 177:751-766

25. Lustgarten JA, Wenk RF 1972 Simple rapid kinetic method for serum creatinine measurement. Clin Chem 18:1419-1422

26. Connerty HV, Briggs AR 1966 Determination of serum calcium by means of orthocresolphtalein complexone. Am J Clin Pathol 45:290-296

27. Daly JA, Ertingshausen G 1972 Direct method for determining inorganic phosphate in serum with the "centrifichem." Clin Chem 18:263-265

28. Bowers GN, McComb RB 1975 Measurement of total alkaline phosphatase activity in human serum. Clin Chem 21:1988-1995
29. Bergmeyer HU, Scheibe P, Wahlefeld AW 1978 Optimization of methods for aspartate arninotransferase and alanine aminotransferase. Clin Chem 24:58 73

30. Rosalki SB 1977 An improved procedure for serum creatine phosphokinase determination. J Lab Clin Med 69:696-705

31. Szasz G, Gerhardt W, Gruber W, Bernt E 1976 Creatin kinase in serum: 2 interference of adenylate kinase with the assay. Clin Chem 22:1806-1811

32. Wacker WEC, Ulmer DD, Vallee BL 1956 Metalloenzymes and myocardia infarction. N Engl J Med 255:449-456

33. Szasz G 1969 A kinetic photometric method for serum gamma-glutamyl transpeptidase. Clin Chem 15:124-136

34. Fisher RA 1980 Statistical Methods for Research Workers. Oliber and Boyd London

35. Bogart MH, Winkel Bauer D, Jones OW 1985 Evaluation of amniotic fluid alpha-fetoprotein using an enzyme-linked immunosorbent assay. Obstet Gynecol 66:341-345

36. Gitlin D, Pernicells A, Gitlin GM, 1972. Synthesis of $\alpha$-feto protein by the liver, yolk-sac and gestational tract of the human conceptus. Cancer Res 32:979-982

37. Aoyagi Y, Ikenaka T, Ichida F 1979 Alphafetoprotein as a carrier protein in plasma and its bilirubin-binding ability. Cancer Res 39:3571-3574

38. Stone RT 1984 Relationship of alpha-fetoprotein and albumin in fetuses and neonates from genetically lean and obese swine. Biol Neonate 46:122-130

39. Christensen N 1974 Lipids in cord serum and fatty acids in plasma of healthy newborns term infants. Acta Pediatr Scand 63:711-714

40. Dyerberg J, Hjorne N, Nymand G 1974 References values for cord blood lipid and lipoprotein concentrations. Acta Pediatr Scand 63:431-436

41. Radde IC, Shami Y, Parkinson DK 1971 The placental calcium pump. Pediatr Res 5:417(abstr)

42. Ramsey GR Jr, Delivoria-Papodopoulos M, Crandell ED. Kronfield DA 1973 Kinetic analysis of calcium transport across the placenta. J Appl Physiol 35:682-693

43. Battaglia FC, Meschia G, 1973. Fetal metabolism and substrate utilization. In Comlina RS, Cross KW, Davies GA, Nathanielsz PW (eds) Fetal and Neonatal Physiology. Barcroft Centenary Symposium. Cambridge University Press, Cambridge, pp 382-397

44. Pearson HA, 1971. Life span of fetal red blood cells. J Pediatr 70:166-177 